\title{
Epidural anesthesia using a $0,75 \%$ ropivacaine and subarachnoid anesthesia with a $0,5 \%$ bupivacaine associated or not with clonidine in hemorroidectomies ${ }^{1}$
}

\author{
Anestesia peridural com ropivacaína a $0,75 \%$ e anestesia subaracnóidea com bupivacaína a \\ $0,5 \%$ associadas ou não à clonidina em hemorroidectomias
}

\author{
João Florêncio de Abreu Baptista', Danilo Nagib Salomão Paulo"I , Isabel Cristina Andreatta Lemos Paulo ${ }^{\mathrm{III}}$, Marcos Célio Brocco ${ }^{\mathrm{IV}}$, \\ Rafael Rodolfo Serafim ${ }^{\text {, }}$, Diego Colodeti ${ }^{\text {VI }}$, Alcino Lázaro da Silva ${ }^{\text {II }}$

\begin{abstract}
${ }^{I}$ Associate Professor, Anesthesiology, Surgical Department, Biomedical Center, Federal University of Espirito Santo and Master in Health Science on the Program of Surgery, Federal University of Minas Gerais (UFMG), Brazil.

II Full Professor of Surgery, School of Medicine, EMESCAN, Espirito Santo, Brazil.

III Assistant Professor of Clinical Surgery, School of Sciences, EMESCAN, Espirito Santo, Brazil.

Iv Associate Professor, Anesthesiology, Surgical Department, Biomedical Center, Federal University of Espirito Santo, Brazil.

${ }^{v}$ Resident Doctor, Anesthesiology, Teaching and Training Department, Biomedical Center, Public Affairs, Espirito Santo, Brazil.

${ }^{V I}$ Intern, $12^{\text {th }}$ Period, Anesthesiology, School of Medicine, Biomedical Center, Federal University of Espirito Santo, Brazil.

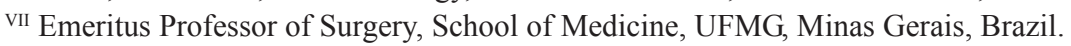

\begin{abstract}
Purpose: To study the safety and efficiency of two anesthetic blockages in hemorroidectomy and the effect of clonidine on analgesia. Methods: 80 patients were studied, randomly divided into four groups: $1(\mathrm{n}=19)$ - peridural with a $0,75 \%$ ropivacaine; 2 (n=21)-peridural with a $0,75 \%$ ropivacaine and $150 \mu \mathrm{g}$ of clonidine; $3(\mathrm{n}=19)$ - subarachnoid with a $0,5 \%$ bupivacaine; 4 ( $\mathrm{n}=21)$ - subarachnoid with a $0,5 \%$ bupivacaine and $50 \mu \mathrm{g}$ of clonidine. The intensity of pain was evaluated by the visual analogical scale 8,12 and 24 hours after surgery. The use of vasoconstrictors on the transoperatory and the amount of analgesics within the 24 hours were registered. Results: The intensity of pain, 8 hours after surgery, was lesser on group 4, and much lesser on group 4 comparing with groups 1 and 2,12 hours $(p=0,022 ; p=0,001)$ and 24 hours $(p=0,03 ; p=0,003)$. The frequency of vasoconstrictors usage on the transoperatory and the analgesics on the post-operatory showed no difference among the groups. There were no anesthetic complications. Conclusions: The subarachnoid anesthesia with a $0,5 \%$ bupivacaine with clonidine, showed better analgesia comparing with the peridural anesthesia with a $0,75 \%$ ropivacaine with or without clonidine, however all were safe and efficient. The clonidine aided on the decreasing of pain when subarachnoid anesthesia was used.
\end{abstract}

Key words: Anesthesia, Epidural. Anesthesia, Spinal. Hemorrhoids. Pain. Clonidine.

\section{RESUMO}

Objetivo: Verificar a segurança e a eficácia de dois bloqueios anestésicos na hemorroidectomia e o efeito da clonidina na analgesia. Métodos: Foram estudados oitenta pacientes, distribuídos aleatoriamente em quatro grupos: 1 ( $\mathrm{n}=19)$ - peridural com ropivacaína a $0,75 \% ; 2(n=21)$-peridural com ropivacaína a $0,75 \%$ e $150 \mu$ g de clonidina; $3(n=19)$-subaranóidea com bupivacaína a $0,5 \%$; $4(\mathrm{n}=21)$ - subaracnóidea com bupivacaína a $0,5 \%$ e $50 \mu \mathrm{g}$ de clonidina. A intensidade da dor foi avaliada pela escala analógica visual 8,12 e 24 horas após a cirurgia. O uso de vasoconstritores no transoperatório, o consumo de analgésicos em 24 horas foram anotados. Resultados: A intensidade da dor, 8 horas após a cirurgia, foi menor no grupo 4, e significantemente menor no grupo 4 em relação aos grupos 1 e 2,12 horas $(p=0,022 ; p=0,001)$ e 24 horas $(p=0,03 ; p=0,003)$. A freqüência do uso de vasoconstritores no transoperatório e de analgésicos no pós-operatório não diferiu entre os grupos. Não houve complicações anestésicas. Conclusões: A anestesia subaracnóidea com bupivacaína a $0,5 \%$, com clonidina, apresentou melhor analgesia que a anestesia peridural com ropivacaína a $0,75 \%$ com ou sem clonidina, porém todas foram seguras e eficazes. A clonidina contribuiu para diminuir a dor na anestesia subracnóidea.

Descritores: Anestesia Eperidural. Raquianestesia. Hemorróidas. Dor. Clonidina.

${ }^{1}$ Research performed at the Cassiano Antonio de Moraes Hospital, Federal University of Espirito Santo, Brazil.

\section{Introduction}

The pain after hemorroidectomy, despite the advance on the analgesia field, is a reality. It can vary from intensity and frequency. Many surgical and anesthetic measures have been used to avoid or to lessen such. It is up to the anesthesiologist to adopt some measures recommending the use of certain medicaments ${ }^{1-10}$, preemptive analgesia ${ }^{11-15}$. Botulinic toxin injection can also be used 
in the internal sphincter ${ }^{16}$ micronized fractions of flavonoids ${ }^{17}$ and the transcutaneous electrical stimulation ${ }^{18}$.

Other analgesia trials have been made with the adding of morphine ${ }^{19,20}$ and clonidine on anesthetic blockages. In hemorroidectomy, under caudal blockage, the clonidine, mixed with bupivacaine, lidocaine and epinefrine, increased the time of analgesia, more than the saline solution added to the same mixture ${ }^{21}$. In proctologic surgeries, especially hemorroidectomy, the clonidine associated with lidocaine and fentanil, in subarachnoid anesthesia, prolonged the time of analgesia, lessened the intensity of pain, with minimum side effects ${ }^{22}$. The clonidine associated with ropivacaine, improved the post-operatory analgesia when epidural anesthesia was used in surgeries performed on the lower part of abdomen ${ }^{23}$. Though, clonidine did not improve the analgesia when used: a- by a catheter near the infraclavicular nerve, in orthopedic surgery of upper $\operatorname{limb}^{24}$; b- on intratecal space in surgeries to remove hip and $\mathrm{knee}^{25}$; c- on interescalenic space, in shoulder surgeries ${ }^{26}$.

Considering that the analgesic efficiency of clonidine is contradictory, and that peridural anesthesia with a $0,75 \%$ ropivacaine and that subarachnoid anesthesia with a $0,5 \%$ bupivacaine have often been used by our anesthesiologists, and that there are no studies that compare these two anesthetic techniques, we put together this paper with the following objectives: Identify on the immediate post-operatory of patients undergone hemorroidectomy, the analgesic efficiency and the safety of peridural with a $0,75 \%$ ropivacaine, associated or not with clonidine and subarachnoid anesthesia with a $0,5 \%$ hyperbaric bupivacaine associated or not with clonidine, and to compare the results from these anesthetic techniques.

\section{Methods}

This paper was approved by the Committee of Research Ethics of the Federal University of Minas Gerais, as per document number ETIC 0478/05. All the patients involved, signed a Term of Previous Informed Consent.

80 patients both men and women, were operated, ages between 20 and 70, ASA 1 or 2, with hemorrhoids of third and fourth degrees (Table 1).

TABLE 1 - Data from patient undergone hemorroidectomy under peridural anesthesia with $0,75 \%$ ropivacaine associated or not with clonidine, and the subarachnoid anesthesia with a $0,5 \%$ bupivacaine associated or not with clonidine

\begin{tabular}{lcccc} 
Types of anesthesia & \multicolumn{2}{c}{ Gender } & Age(years) & \multicolumn{1}{c}{ BMI(Kg/m2) } \\
& Male Female & A.A S.D & A.A S.D \\
\hline Peridural with $0,75 \%$ ropivacaine & 6 & 13 & $50,0 \pm 7,3$ & $24,36 \pm 4,12$ \\
& & & & \\
Peridural with $0,75 \%$ ropivacaine & 9 & 12 & $46,3 \pm 10,3$ & $24,86 \pm 5,96$
\end{tabular}

Associated with clonidine

subarachnoid with a $0,5 \%$

bupivacaine

6

13

$43,1 \pm 14,1$

$23,59 \pm 2,65$

subarachnoid with a

$0,5 \%$ bupivacaine

9

12

$49,8 \pm 11,6$

$25,21 \pm 4,92$

Associated with clonidine

A.A- Arithmetical average S.D- Standard Deviation $\quad$ BMI- Body Mass Index

The following criteria were adopted to select the patients:

1- Exclusion Criterion: patients suffering from lesion or fistula, with serious heart and respiratory disease, diabetes, with alter psquism, chronic and painful disorder; frequent users of analgesics; and the ones allergic to any analgesic drug;

2- Inclusion Criterion: patients with no surgical counterindication, with hemorrhoids of third and fourth degrees.
The patients were randomly divided into four groups according with the type of anesthesia dispensed: group 1 $(\mathrm{n}=19)$ :- peridural anesthesia with $14 \mathrm{~mL}$ of $0,75 \%$ ropivacaine (Cristalia - Itapira- São Paulo- Brazil), plus $1 \mathrm{~mL}$ saline solution; group $2(n=21)$ :- peridural anesthesia with $14 \mathrm{~mL}$ of $0,75 \%$ ropivacaine added with $1 \mathrm{~mL}$ of clonidine (Cristalia); group 3 $(\mathrm{n}=19)$ :- rachianesthesia with $2,0 \mathrm{~mL}$ of $0,5 \%$ weighted 
bupivacaine (Cristalia); group $4(\mathrm{n}=21)$ - rachianesthesia with 2,0 $\mathrm{mL}$ of hyperbaric bupivacaine (Cristalia) plus $0,33 \mathrm{~mL}$ of clonidine.

On patients ready for surgery, the colon was prepared using a bottle of enema (sodium phosphate monobasic $\mathrm{H}_{2} 016 \mathrm{~g}$, and sodium phosphate dibasic $\mathrm{H}_{2} 06 \mathrm{~g}$ ), administered via rectum 10 hours before surgery. Midazolan, 7,5 mg was used as preanesthetic sublingual medication one hour before surgery. A vein was punched from the upper limb (back of hand or anterior of forearm), using an I.V catheter 20 to infuse saline solution and medicaments. All the patients were monitored using ECG, oximetry of pulse and non-invasive arterial pressure, with values written down on anesthetic file.
The epidural puncture was performed using a Tuohy $15 \mathrm{G}$ needle, on the space between L3-L4, with patients sitting down. The drugs were injected in the peridural space, volume of $15 \mathrm{~mL}$, and velocity of approximately $1 \mathrm{~mL} / \mathrm{second}$. The unilateral spinal puncture was performed with a $27 \mathrm{G}$ needle on the space between L3- L4, using a injector to make the puncture easier and to injection of medication, proved to be efficient against the risk of headache after surgery. The velocity of solution injection was about $1 \mathrm{~mL} / 15$ second. After about 5 minutes, a rectum touch was performed by the surgeon in order to evaluate the degree of sphincter relaxing. A value was attributed from $0-10$ according with the degree of relaxing (Table 2).

TABLE 2 - Degree of sphincter relaxing in patients undergone hemorroidectomy under peridural
anesthesia with $0,75 \%$ ropivacaine associated or not with clonidine, and the subarachnoid anesthesia
with $0,5 \%$ bupivacaine associated or not with clonidine

Sphincter Relaxing

Groups Types of anesthesia

\begin{tabular}{|c|c|c|c|c|c|c|}
\hline & & A.A & S.D & $\mathrm{p}$ & $\mathrm{p} 1$ & p2 \\
\hline $1-$ & Peridural with $0,75 \%$ ropivacaine & 6,69 & 1,96 & & & \\
\hline $2-$ & $\begin{array}{l}\text { Peridural with } 0,75 \% \text { ropivacaine } \\
\text { associated with clonidine }\end{array}$ & 6,76 & 1,92 & NS & & \\
\hline \multirow[t]{2}{*}{$3-$} & subarachnoid with & & & & & \\
\hline & a $0,5 \%$ bupivacaine & 8,00 & 1,37 & $<0,05$ & $<0,05$ & \\
\hline $4-$ & $\begin{array}{l}\text { subarachnoid with a } 0,5 \% \text { bupivacaine } \\
\text { associated with clonidine }\end{array}$ & 8,00 & 1,55 & $<0,05$ & $<0,05$ & NS \\
\hline
\end{tabular}

\begin{abstract}
A.A- Arithmetical Average S.D- standard deviation
Kruskal Wallis. p- comparing the groups 2, 3 and 4 with group 1. p1- comparing groups 3 and 4 with group 2. p2- comparing between group 3 and 4 . NS- non significant. p, p1,p2 $<0.05$ - significant
\end{abstract}

The hemorroidectomy technique was performed only by the surgeon on duty, the semiclosed technique was used (Milligan Morgan technique associated with Fergusson).

The safety of anesthetic techniques was evaluated by monitoring the transoperatory arterial pressure, pulse, Sat02 and breathing, besides the electrocardiographic tracing. Each patient whose blood pressure dropped beyond $20 \%$ from the initial value, were treated with vasoconstrictors. The vital signals were also evaluated 20 minutes after surgery, four hours, eight hours, 12 hours, and the usual 24 hours and/or in other situations when necessary.

The analgesic efficiency of anesthetic techniques was evaluated by intensity of pain and by consumption of analgesics. The intensity of post-operatory pain was evaluated by a scale of visual analogy (EAV) 8, 12 and 24 hours after beginning the anesthesia, or at other time when it was necessary. On this scale, zero represents the absence of pain, and 10, the presence of intense pain (unbearable). The frequency of analgesic usage within 24 hours was also calculated. All patients had their data written down on a special file.

After hemorroidectomy, the patients received endovenous, $100 \mathrm{mg}$ cetoprofene and $1 \mathrm{~g}$ dipirone and were strictly observed on post-anesthetic recovery by a professional that didn't participate on the procedure, however, accompanied them during a 24-hour period, after surgery was finished.

The following statistics were used: a- Descriptive Statistics to calculate the arithmetic average (A.A) and (S.D) standard deviation of variables: age, height, weight, BMI, surgical duration, EAV- 8 hours, EAV-12 hours, EAV-24 hours; and the 
variable frequency when necessary; b- Correlation test of Spearman to correlate the BMI, age, operation duration with the EAV; c- chi-squared statistic to compare the number of male patients with the female ones; d- Fisher exact statistics to compare the frequency of patients that used analgesic and vasoconstrictor comparing with the ones that didn't use such; e- Kruskal-Wallis test to compare the surgical duration, BMI, age, the EAV (8-12-24 hours) and the sphincter relaxing among the four groups b; f- Doon Multiple comparison (post-hoc) when the Kruskal Wallis test showed significance. A $p<0,05$ value was considered statistically significant.

\section{Results}

The hemorroidectomy procedures were performed with no difficulties, an average time of $21 \pm 8,1$ minutes, and there were no post-operatory complications related with this operation.

There was no significant difference between the number of male or female patients, average age, BMI and operation average duration on the four groups $(\mathrm{p}>0.05)$.

There was no correlation between intensity of pain and BMI ( $\mathrm{p}>0.05)$.

No correlation between operation duration and intensity of pain was found, except on patients undergone peridural anesthesia without clonidine, after 8 and 24 hours $(\mathrm{p}<0.05)$. The pain was more intense on patients that had a more prolonged surgery period. There was no correlation between intensity of pain at 8,12 and 24 hours and age of patient ( $p>0.05$ ).

The rachianesthesia and peridural anesthesia were performed without any incident. Both associated or not with clonidine, proved to be safe. The monitoring of non-invasive arterial pressure, determined by Riva-Rocci method, the electrocardioscopy on derivations $\mathrm{D}_{\mathrm{II}}$ e $\mathrm{V}_{\mathrm{I}}$, used also to measure the cardio-frequency, and the pulse oximetry to measure the hemoglobin saturation $\left(\mathrm{SpO}_{2}\right)$ didn't suffer unexpected alterations. There was no significant statistical difference among the groups on the frequency of vasoconstrictor usage on the transoperatory $(\mathrm{p}>0.05)$ (Table 1).

Both analgesic techniques were efficient to treat pain. Though, the intensity of pain 8 hours after hemorroidectomy had no difference among the groups (Figure 1). The intensity of pain, 12 hours after hemorroidectomy, was lesser on the group of patients submitted to rachianesthesia with clonidine comparing with peridural without clonidine $(\mathrm{p}<0.05)$ and peridural with clonidine $(\mathrm{p}<0.05)$ and had no difference from rachianesthesia without clonidine $(\mathrm{p}>0,05)$ (Figure 1$)$.
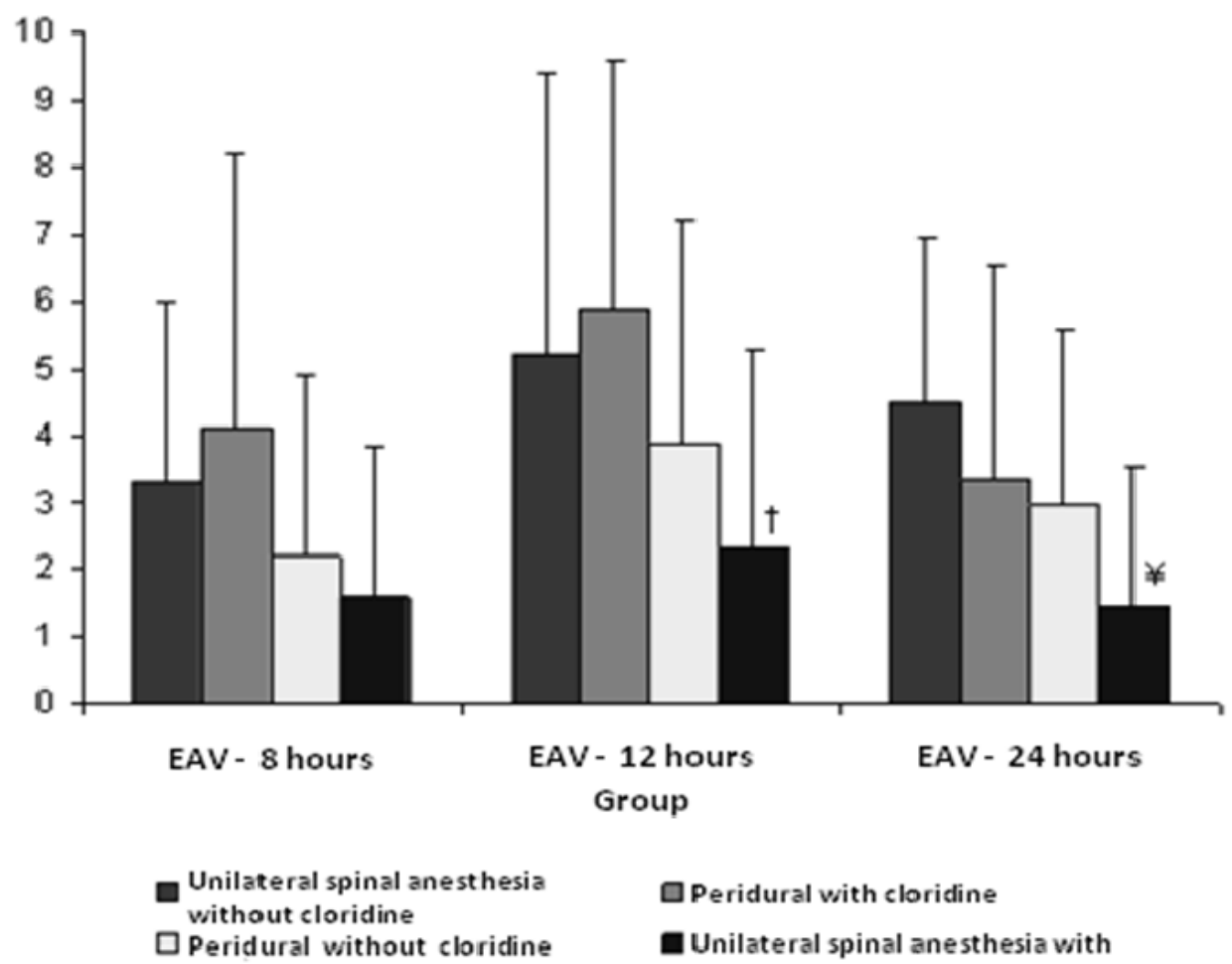

Deridural with cloridine

Unilateral spinal anesthesia with cloridine

FIGURE 1 - Intensity of pain (EAV) 8, 12 and 24 hours after hemorroidectomy among the four groups of patients: 1-. Peridural Anesthesia without clonidine, 2- Peridural Anesthesia with clonidine; 3- Rachianesthesia without clonidine; 4- Rachianesthesia with clonidine. The column represents the average of variable; the straight segment over the column represents the standard-deviation. $*$ or $\uparrow$ - significant between groups 2 and 4 and between groups 1 and 4 . Kruskal Wallis 
The intensity of pain 24 hours after surgery was lesser on patients submitted to rachianesthesia with clonidine, unlike patients submitted to peridural with clonidine $(\mathrm{p}<0.05)$ and peridural without clonidine $(p<0.05)$; there was no difference on the intensity of pain on groups 3 and 4 (Figure 1). There was no difference on consumption of analgesics among the four groups ( $>0.05$ ) on postoperative (Table 3 ).

TABLE 3 - Analgesic on Post-operatory (8, 12, 24 hours) and vasoconstrictors on transoperatory, in patients undergone hemorroidectomy under peridural anesthesia and Rachianesthesia, with or without clonidine

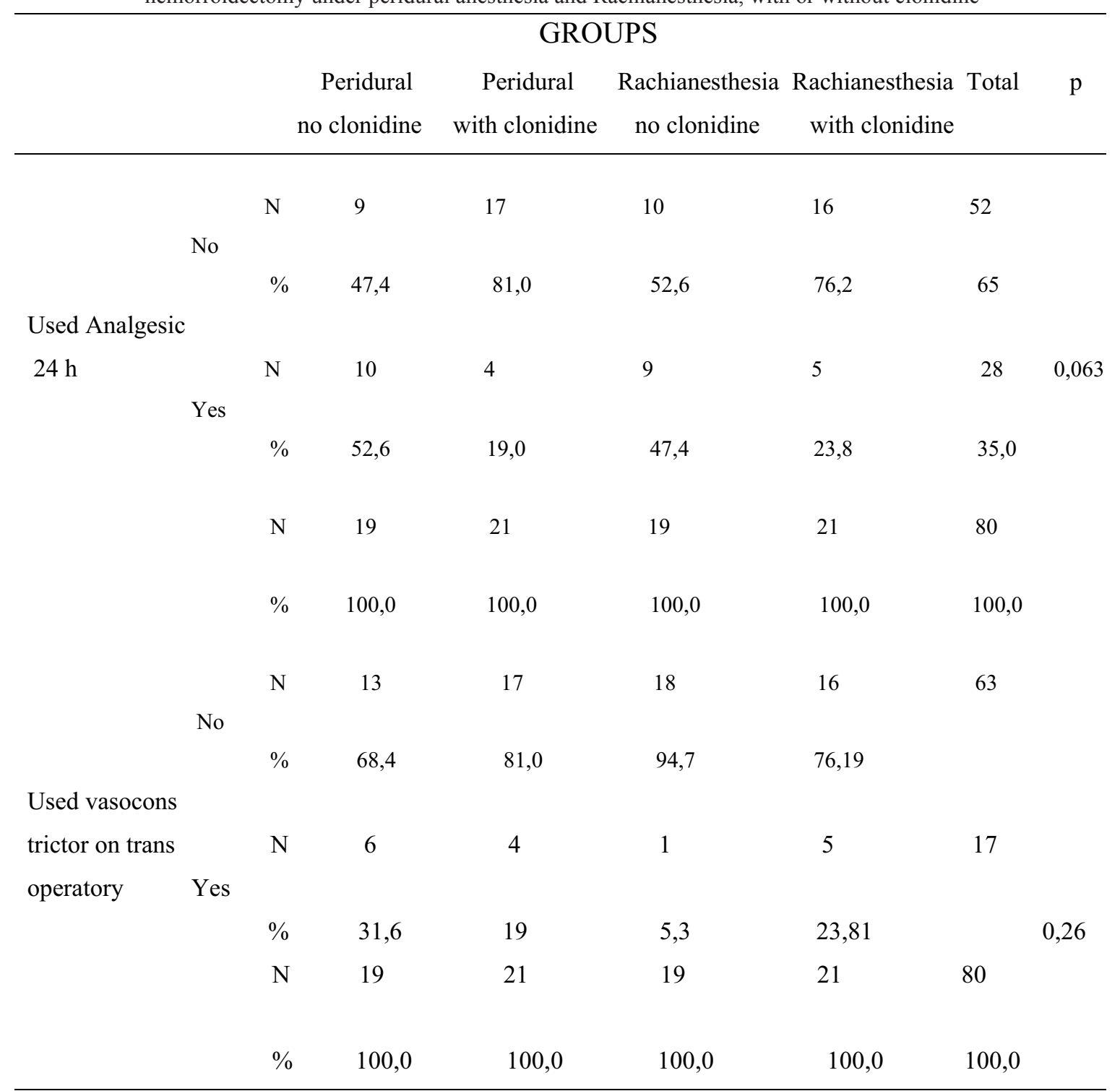

Exact Fisher Test. N- number of people. $\mathrm{p}>0.05$ - non significant

The patients submitted to rachianesthesia presented better muscle relaxing, therefore making the surgery easier (Table 2).

\section{Discussion}

The semiclosed hemorroidectomy technique was used on all patients; scalpel with removable blades and conventional surgical material (nippers, scissors); electrical scalpel was used to section the anal mucosa, and the surgeries were performed by only one surgeon. It's important to mention that on this experiment, there was no significant statistical difference in age, gender, and duration of operation on the different groups. This, to a certain extend, allowed the team to control variables that could interfere on the results and make comparisons among the groups, because the intention was to simply verify the effect of variable "anesthesia associated or not with clonidine", on post-operatory pain.

The analgesics used were cetoprofene $(100 \mathrm{mg})$ and dipirone ( $1 \mathrm{~g}$ ) endovenose right after surgery, and was performed again in case of presence of pain. The local application 
medications ${ }^{1-3}$, administered on the muscle ${ }^{4-7}$ or other site $^{8-15}$, as well as the approved resources in the literature to treat or avoid pain ${ }^{16-18}$ were not used for we wouldn't have a variable that could interfere on the pain process.

The analyses from the results of this work, showed that the subarachnoid anesthesia with a $0,5 \%$ bupivacaine and the epidural anesthesia with a $0,75 \%$ ropivacaine with or without clonidine were both safe. The hemodynamic alterations that happened during the blockage were absolutely predictable and the use of vasoconstrictors didn't interfere among the groups ( $p>0.05)$. It's important to point out that clonidine causes hypotension and bradycardia because it activates the $\alpha 2$ - pre-synaptic adrenoceptors, on peripheric nerve termination, inhibiting the exocytose of noradrenaline ${ }^{35}$. Besides that, the hypotension is caused by the activation of the center of vasomotor on CNS, with decreasing of sympathetic efflux and reducing the circulating catecholamine with potential parasympath nerve activity, decreasing this way, the arterial pressure ${ }^{36}$. But, clonidine caused vasoconstriction because it activated the post-synaptic receptors on the flat musculature of arteries and veins ${ }^{36}$.

When the intensity of pain was compared among the groups, eight hours after hemorroidectomy, we observe that the pain was less intensive when using rachianesthesia with clonidine other than peridural without clonidine and peridural with clonidine. This can be associated with the major muscular relaxing caused by the rachianesthesia and by a possible analgesic effect from clonidine that was present at that period. The pain was also less intense in patients undergone rachianesthesia with clonidine comparing with peridural with clonidine $(\mathrm{p}<0.05)$ peridural without clonidine $(p<0,05), 12$ hours after surgery. This happened 24 hours after hemorroidectomy, when this kind of anesthesia was compared with peridural with clonidine $(\mathrm{p}<0.05)$, and peridural without clonidine $(p<0.05)$. Although no difference on the intensity of pain between the two kinds of rachianesthesia was shown. Besides that, there was no significant statistical difference on the frequency when using the analgesic among the four groups $(\mathrm{p}>0,05)$. This shows that the rachianesthesia is more efficient than the peridural and that clonidine helped decreasing the post-operatory pain when associated with rachianesthesia. The fact that rachianesthesia produces good muscular relaxing and consequently making the operation easier, producing less trauma could justify the less intensity of pain. In fact, the subarachnoid anesthesia produced more sphincter relaxing than the peridural anesthesia (Table 2).

We observed that the clonidine associated with ropivacaine on peridural anesthesia, did not interfere on pain, 8 and 12 hours after surgery. On rachianesthesia the clonidine helped reducing pain 8, 12 and 24 hours after surgery. We can observe that when the comparison of value between the groups that used clonidine on rachianesthesia and the ones that didn't was made.

The clonidine used on the blockages, shows controversial results. On hemorroidectomy, under caudal blockage, it was associated with a mixture of bupivacaine, lidocaine and epinefrine, caused more prolonged analgesia than the saline solution added to such mixture ${ }^{21}$. On proctologic surgeries, especially hemorroidectomy, the clonidine associated with lidocaine and fentanil, on subarachnoid anesthesia, prolonged the time of analgesia, reducing the intensity of pain, with minimum side effects $^{22}$. Both, clonidine and ropivacaine, improved the postoperatory analgesia, when used under different blockages and types of surgery ${ }^{23-25,32}$. Some studies, though, claim that this drug does not improve analgesia when also taken by different ways and in different types of surgery ${ }^{24-26}$. This study showed that clonidine helped decreasing pain when used on rachianesthesia, although on this anesthesia, the dosage had been smaller than on peridural anesthesia. This drug on the subarachnoid space produced more intense and selective effects than the ones observed with similar dosage on epidural space ${ }^{33}$. It's important to emphasize that the dosage and via of administration of clonidine, interfered on its analgesic action $^{36}$.

\section{Conclusion}

The subarachnoid anesthesia with a $0,5 \%$ bupivacaine with clonidine, showed better analgesia than epidural anesthesia with a $0,75 \%$ ropivacaine with or without clonidine, though all proved to be safe and efficient.

\section{References}

1. Wasvary HJ, Hain J, Mosed-Vogel M, Bendick P, Barkel DC, Klein SN Wasvary HJ, Hain J, Mosed-Vogel M, Bendick P, Barkel DC, Klein SN. Randomized, prospective, double-blind, placebo-controlled trial of effect of nitroglycerin ointment on pain after hemorroidectomy. Dis Colon Rectum. 2001;44(8):1069-73.

2. Coskun A, Duzgun SA, Uzunkoy A, Bozer M, Aslan O, Canbeyli B. Nitroderm TTS band aplication for pain after hemorroidectomy. Dis Colon Rectum. 2001;44(5):680-5.

3. Nicholson TJ, Armstrong D. Topical metronidazole (10 percent) decreases posthemorrhoidectomy pain and improves healing. Dis Colon Rectum. 2004;47(5):711-6.

4. Aasboe V, Raeder JC, Groegaard B. Betamethasone reduces postoperative pain and náusea after ambulatory surgery. Anesth Analg. 1998;87(2):319-23.

5. Liu ST, Wu CT, Yeh CC, Ho ST, Wong CS, Jao SW, Wu CC, Kang JC. Premedication with dextromethorphan provides posthemorrhoidectomy pain relief. Dis Colon Rectum. 2000;43(4):507-10.

6. Basile M, Gidaro S, Pacella M, Biffignandi PM, Gidaro GS. Parenteral troxerutin and carbazochrome combination in the treatment of post-hemorroidectomy status: a randomized, double-blind, placebocontrolled trial, phase IV study. Curr Med Res Opin. 2001;17(4):256-61. 7. Magrini M, Rivolta G, Bolis C, Furiosi D. Analgesic activity of tramadol and pentazocine in postoperative pain. Int Clin Pharmacol Res. 1998;18(2):87-92.

8. Kibride M, Morse M, Senagore A. Transdermal fentanyl improves management of postoperative hemorrhoidectomy pain. Dis Colon Rectum. 1994;37(11):1070-1.

9. O'Donovan S, Ferrara A, Larach S, Williamson P. Intraoperative use of toradol facilitates outpatient hemorrhoidectomy. Dis Colon Rectum. 1994;37(8):793-9.

10. Goldstein ET, Williamson PR, Larach SW. Subcutaneous morphine pump for postoperative hemorrhoidectomy pain management. Dis Colon Rectum. 1993;36(5):439-46.

11. Luck AJ, Hewett PJ. Ischiorectal fossa block decreases posthemorrhoidectomy pain: randomized, prospective, double- blind clinical trial. Dis Colon Rectum. 2000;43(2):142-5.

12. Morisaki H, Masuda J, Fukushima K,I wao Y, Suzuki K, Matsushima M. Wound infiltration with lidocaine prolongs postoperative analgesia after hemorroidectomy with spinal anaesthesia. Can J Anaesth. 1996;43(9):914-8.

13. Jirasiritham S, Tantivitayatan K, Jirasiritham S. Perianal blockage with $0,5 \%$ bupivacaine for postoperative pain relief in hemorroidectomy. J Med Assoc Thai. 2004;87(6):660-4. 
14. Brunat G, Pouzeratte Y, Mann C, Didelot JM, Rochon JC, Eledjam JJ. Posterior perineal block with ropivacaine $0,75 \%$ for pain control during and after hemorroidectomy. Reg Anesth Pain Med. 2003;28(3):228-32. 15. Vinson-Bonnet B, Coltat JC, Fingerhut A, Bonnet F. Local infiltration with ropivacaine improves immediate postoperative pain control after hemorrhoidal surgery. Dis Colon Rectum. 2002;45(1):104-8.

16. Davies J, Duffy D, Boyt N, Aghahoseini A, Alexander D, Leveson S. Botulinum toxin (botox) reduces pain after hemorroidectomy: results of a doublé-blind, randomized study. Dis Colon Rectum. 2003;46(8):1097-102. 17. Colak T, Akca T, Dirlik M, Kanik A, Dag A, Aydin S. Micronized flavonoids in pain control after hemorroidectomy: a prospective randomized controlled study. Surg Today. 2003;33(11):828-32.

18. Chiu JH, Chen WS, Chen CH, Jiang JK, Tang GJ, Lui WY, Lin JK. Effect of transcutaneous electrical nerve stimulation for pain relief on patients undergoing hemorroidectomy: prospective, randomized, controlled trial. Dis Colon Rectum. 1999;42(2):180-5.

19. Amanor-Boadu SD. Assessment of minidose intrathecal morphine for analgesia after hemorrhoidectomy. West Afr J Med. 1992;11(2):146-9.

20. Chen KP, Chan HC, Chen FS, Wong CH, Chuah EC, Tan PP. Lumbar extradural morphine and caudal extradural morphine for postoperative analgesia and their adverse effects. Ma Zui Xue Za Zhi. 1993;31(1):25-30. 21. Van Elstraete AC, Pastureau F, Lebrun T, Mehdaoui H. Caudal clonidine for postoperative analgesia in adults. Br J Anaesth. 2000;84(3):401-2. 22. Martinez Gonzalez L, Léon Vázques AR, Pajon SAO. Clonidine intratecal para alivio del dolor posoperatório em cirugia proctológica: su combinacion com otros agentes. Rev Cub Cir. 2000;40(4):297-304.

23. Alves TCA, Braz JRC. Surgery of the lower part of the abdomen, effects when associating clonidine to ropivacaine on anesthesia peridural. Rev Bras Anestesiol. 2002;52(4):410-9.

24. Ilfeld BM, Morey TE, Enneking FK. Continuous infraclavicular perineural infusion with clonidine and ropivacaine compared with ropivacaine alone: a randomized, double-blind, controlled study. Anesth Analg. 2003;97(3):706-12.

25. Geniing M, Tryba M, Lusebrink I, Zorn A. Can the addition of clonidine improve the analgesic efficacy of low dose intrathecal morphine? A randomized double-blind trial. Anaesthesist. 2003;52(3):204-9.
26. Esteves S, Sá P, Figueiredo D, Pèrez Souto A. Duration and quality of postoperative analgesia after brachial plexus block for shoulder surgery: ropivacaine $0,5 \%$ versus ropivacaine $0,5 \%$ plus clonidine. Rev Esp Anestesiol Reanim. 2002;49(6):302-5.

27. Khubchandani IT. Internal sphincterotomy with hemorrhoidectomy does not relieve pain: a prospective randomized study. Dis Colon Rectum. 2002;45(11):1452-7.

28. Andrews BT, Layer GT, Jackson BT, Nicholls RJ. Randomized trial comparing diathermy hemorrhoidectomy with the scissor dissection Milligan-Morgan operation. Dis Colon Rectum. 1993;36(6):580-3.

29. Khan S, Pawlak SE, Eggenberger JC, Lee CS, Szilagy EJ, Wu JS, Margolin MDDA. Surgical treatment of hemorrhoids: prospective, tandomized trial comparing closed excisional hemorrhoidectomy and the Harmonic Scalpel technique of excisional hemorrhoidectomy. Dis colon Rectum. 2001;44(6):845-9.

30. Sutherland LM, Burchard AK, Matsuda K, Sweeney JL, Bokey EL, Childs PA, Roberts AK, Waxman BP, Maddern GJ. systematic review of stapled hemorrhoidectomy. Arch Surg. 2002;137(12):1395-406.

31. Hussein MK, Taha AM, Haddad FF, Bassim YR. Bupivacaine local injection in anorectal surgery. Int Surg. 1998;83(1):56-7.

32. Klamt JG, Garcia LV, Stocche RM, Meinberg AC. Epidural infusion of clonidine or clonidine plus ropivacaine for postoperative analgesia in children undergoing major abdominal surgery. J Clin Anesth. 2003;15(7):510-4.

33. Eisenach JC, De Koch M, Klimsha W. a -adrenergic agonists for regional anesthesia. Anesthesiology. 1996;85:655-74.

34. Braz JRC, Koguti ES, Braz LG. Efeitos da associação da clonidine à bupivacaína hiperbárica na anesthesia subaracnóide alta. Rev Bras Anestesiol. 2003;53:561-72.

35. De Jonge A, Timmermans PB, Van Zweiten PA. Participation of cardiac presynaptic a2-adrenoceptors in the bradycardic effects of clonidine and analogues. Naunyn Schmiedebergs Arch Phramacol. 1981;137:8-12.

36. Klimsha W, Chiari A, Krafft P, Plattner O, Taslimi R, Mayer N, Weinstabi C, Schneider B, Zimpfer M. Hemodynamic and analgesic effects of clonidine added repetitively to continuous epidural and spinal blocks. Anesth Analg. 1995;80:322-7.

\section{Correspondence:}

Prof. Alcino Lázaro da Silva

R. Guaratinga, 151

30315-430 Belo Horizonte - MG Brazil

Conflict of interest: none

Financial source: Department of Clinical and Experimental Support, Institute of Sustainable Development

30315-430 Belo Horizonte - MG Brazil

Received: May 20, 2008

Review: July 15, 2008

Accepted: August 14, 2008

\section{How to cite this article}

Baptista JFA, Paulo DNS, Paulo ICAL, Brocco MC, Serafim RR, Colodeti D, Silva AL. Epidural anesthesia using a 0,75\% ropivacaine and subarachnoid anesthesia with a $0,5 \%$ bupivacaine associated or not with clonidine in hemorroidectomies. Acta Cir Bras. [serial on the Internet] 2008 Nov-Dec;23(6). Available from URL: http://www.scielo.br/acb 